\title{
Report
}

\section{The Financial Sector as Stewards for the Sustainable}

\section{Development Goals}

\author{
Herman Mulder ${ }^{1 *}$ \\ 1 Member Nyenrode Corporate Governance Institute (NCGI), Nyenrode Business University, \\ Breukelen, the Netherlands
}

Received: April 8, 2019

Accepted: April 15, 2019

Online Published: April 24, 2019

doi:10.22158/jepf.v5n2p183

URL: http://dx.doi.org/10.22158/jepf.v5n2p183

\section{The best of times, the worst of times:}

As in Charles Dickens' novel "A Tale of Two Cities", we seem to be living in "the best of times and the worst of times", with hopefully "resurrection" (after the 1789 French Revolution though) or, in current jargon, societal, economic, technological "transformation", fitting a modern, inclusive, just, prosperous, fair, peaceful world.

Social justice, nature conservation and economic fairness are essential elements for "the world we want", as articulated in the UN Sustainable Development Goals (the SDGs) for the period 2015-2030. With its 17 Goals, 169 targets and 234+ indicators it is, together with the Paris Agreement on Climate Change and the Addis Action Agenda on Financing for Development, a powerful, global, universal driver for positive change, "leaving no one behind", "from us all, by us all for us all".

\section{We have a mission and a roadmap, but...:}

Since the adoption of the SDGSs, many governmental, business, civil society leaders and scholars have embraced the narrative and incorporated the mission in their strategies. The transition process towards realizing the SDGS is both hopeful ("the best of times"), but also painful ("the worst of times") as our societies are in the midst of transformation while facing key issues such as poverty, inequality, exclusion, climate change, pollution, resource-depletion, migration, governance-deficiencies (many of which are underpinning the need for the SDGs ambition).

Our mission is complicated by a variety of vocal sceptics among traditional industries, blue collar workers, political nationalists/populists as well as the many "innocents" focusing foremost on short term self-interest rather than also recognizing the broader interests benefitting those as well in the long term. 


\section{Time for a fundamental reset of the financial sector:}

The financial sector (banks, pension funds, insurance companies, private equity) have a particular duty and an opportunity to assume a key role in the realization of the Sustainable Development Goals (the SDGs) by stewardship and capital mobilization.

By clearly serving its stakeholders and society-at-large this way, it may also restore the trust in the sector which it lost in the 2008 financial crisis. The financial sector has been made aware of its key role in the welfare and wellbeing of society. IT has, since the crisis, significantly improved its mission and practice, and should now be fit and ready to really step-up to the plate of long term value creation for its stakeholders and society-at-large. Making a tangible contribution through knowledge, innovation and the mobilization of catalytic capital it may drive the acceleration of the tipping point for SDG implementation at scale, as is urgently required.

\section{The numbers are big, the practice too slow:}

The estimated incremental investments to realize the universal, global SDGs (with its 17 Goals, as adopted by the UN in 2015 and embraced by 198 countries, "from us all, by us all, for us all", by 2030) is $\$ 7,5 \operatorname{trln}$ p.a., of which the private financial sector is considered to contribute annually $\$ 2,5 \operatorname{trln}$, or $4-5 \%$ of its total asset base (every year!); the sector is currently not even close to this, as currently only some $5 \%$ of total assets is deemed and/or targeted to be SDG-related.

The SDGs implementation would create, globally, new business opportunities for its clients, investees and itself by 2030 of some $\$ 12-20 \operatorname{trln}$ p.a. At the same time, the transition risks related to technological, societal and environmental (including climate change) pressures and transformations will fundamentally change many traditional industries, business models and customers' behaviors.

In other words, the financial sector has, hence, a defensive imperative and an offensive reason to drive the SDG agenda, for themselves, its stakeholders and society-at-large. The question is: can and will the financial sector step up, and if not, what is holding it back?

\section{A global Opportunity Agenda as powerful business case:}

The SDGs are a comprehensive, universal commitment by 198 countries to address the material challenges facing us: it is both a repair- and an innovation- job. It is also a moral compass "from us all", setting a comprehensive agenda "for us all", to be implemented in a SMART way "by us all": it is a lever for innovation and cooperation across stakeholders.

The SDGs offer a powerful narrative and agenda, are an opportunity for business to make a positive contribution to society and a strong business case for itself. The 2017 "Better Business, Better World" Report by the Business \& Sustainable Development Commission (BCSD) has illustrated this for 4 High Added Value Systems: Food \& Agriculture, Cities, Energy \& Materials, Health \& Wellbeing at \$12trln of new business yearly, with an estimated additional yearly $\$ 8$ trln for other systems. As a reference, the Global GDP was in 2017 \$80trln. 


\section{Normative "do no harm"- baselines:}

The SDGs are conditioned by adherence to norms'-based Environmental, Social and Governance (ESG) principles which address the duty of business to prevent, reduce or mitigate material adverse impacts in their value chains by their investments and operations. Among the many standards, the overarching 2011 OECD Guidelines for Multinational Enterprises (OECD MNE GLs) and the 2011 UN Guiding Principles for Business and Human Rights (UNGPs) set clear, multi-faceted baselines for business. These ESG baselines are voluntary for business, but not without consequences: over time "there is no law-free zone".

\section{"Making markets fit for purpose":}

To accelerate and scale the collective efforts "for the world we want", ambition and important system change is required to enable business to make its contribution: markets are inefficient and dysfunctional, prices and valuations are misleading about the underlying long term value (even if assured by external auditors), and the client has often a short term and narrow-focus bias: our financial capital market system is one-dimensional (at best) or even blind. Adam Smith's "invisible hand of the market" has become similar to the "emperor's new clothes". A "clear pathway for better" is emerging with the universal, global narrative and objective (realization of the 17 Goals of the SDGs by 2030), the multi-capital "integrating thinking" and practice by an increasing number of business leaders and improved accountability by advanced disclosure and (sustainability and integrated) reporting.

\section{Integrated Risk, Return and Impact as the new paradigm:}

Prudent and responsible investing of the deposits and savings from funding clients of ther financial sector requires next to financial market returns, also due consideration for how financial markets, the real economy and society-at-large may evolve. Key themes are, inter alia, human justice, climate change, biodiversity and natural resource losses. Short term returns and limiting investment losses will always be necessary, but equally important is avoiding potential future asset value impairment, reputation losses and, even, $3^{\text {rd }}$ party claims due to being directly linked to adverse societal impacts. Inevitably, through markets and/or regulations, "impact investing" (currently at only $\$ 0,5 \operatorname{trln}$ ) will evolve from an oxymoron (in the past) to a high-growth asset class (today's practice) to mainstream: long term investing will be serving, as good practice, both the direct and indirect interests of the primary clients, other direct stakeholders and society-at-large. This is core to the emerging integrated Risk, Return and Impact Paradigm.

\section{"Integrated thinking" as strategic approach for business:}

Integrated thinking is embracing "multi-capitalism" (financial, natural, social, human manufactured, intellectual capitals), and identifying, even monetizing material externalities and impacts, i.e. both the costs and benefits for stakeholders of such capitals by business operations and financing interventions, 
leading to an "integrated profit \& loss"-approach.

The "do no harm" and "doing good and well" frameworks offer an integrated strategic framework for business, including the financial sector. This means that business may focus in its strategies on its chosen (2-5) SDGs, but should not ignore the other SDGs ("leave no SDG behind"), as well as adhere to the ESG "do no harm" baselines. The ESG baselines and the SDG business opportunity apply both to the entire value chain: business is expected to apply its leverage in the case of (actual or potential) adverse impacts. Also, it may encourage and assist its business partners (including investees) to contribute to the SDGs, for the benefit of itself, its business partners and society. Such leverage should focus on material issues (for all stakeholders) and is proportionate to the size (or "cloud") of such business.

\section{Due diligence and leverage in the value chain:}

Initial and ongoing, risk-based, impact sensitive due diligence and leverage in the value chain need to be based on robust information, including from advanced disclosure by borrowing customers, bond issuers and other investees, and is of the essence for balanced defensive "do no harm-" and offensive "doing good and well-" strategies. The costs associated herewith may be considered an insurance premium against potential reputational and financial losses, or as an investment in a better (long term) performing investment portfolio.

\section{Emerging impact approaches:}

An emerging growth area for is bond issuers and investors is thematic investing (including the use indexes). These are "smart passive" or even "active" as they focus on a particular set of priorities by the investor and investee, and are monitored on their performance and impact. Green bonds (SDG\#7: Renewable Energy (SDG\#13: Climate Change), Education Bonds (SDG\#4) are already widely applied but, no doubt, other thematic investing classes will develop, linked to the SDGs in general or a subset thereof.

\section{Governments to "crowd-in" business:}

Mainstreaming of new concepts, acceleration and scaling of ambitions and plans (such as the SDGs) can only be effected if governments step-up by removing obstacles and providing incentives for business "to be crowded into" the public agenda by "making markets work for purpose", creating a coherent pro-SDG ecosystem with smart regulatory and fiscal interventions and instruments. In this context, cases in kind are the recommendations from the Task Force on Climate-related Financial Disclosures (TCFD) and the proposed EU Commission Action Plan for the Financing of Sustainable Growth. Blended finance, a key aspect in the Addis Ababa Action Agenda, needs to be further developed and applied at scale with new complementary funding and risk-distribution approaches, such as Social or Development Impact Bonds (with a government as "outcome payor"), new-generation 
partial risk guarantees for de-risking (similar to export credit risk coverage).

\section{Supporting long term value creation:}

With their intimate understanding of their individual clients, their industrial and economic insights and oversights, banks make extremely well-qualified advisors to their (business and retail) customers to take the right strategic and associated investment decisions.

Private equity may play an even more forceful role in this.

Clients of pension funds and insurance companies have a dual interest: enjoying now and in the future a decent pension, while living in a prosperous, just and peaceful society. The fiduciary duty of pension funds should not only relate to the direct best interests of their primary beneficiaries, but also to contributing, within their chosen roles and resources, to society-at-large and thereby more indirectly benefitting such clients.

\section{Accelerate the tipping point for scale!}

How do we get there in a world with major societal and transition risks? For the systemic actors of the financial sector (1) redefining its core purpose as being stewards, by advice and capital mobilization, towards responsible, sustainable value creation for its customers, beneficiaries, investees and society-at-large, (2) by striving for a fair Risk, Return and Impact balance, (3) by "being smarter", by applying a "multi-capitals-“ approach (financial, manufactured, human, social, intellectual, natural capitals) and considering material "externalities" in pricing and valuations (by true pricing and integrated P\&L approaches), (4) by "speaking louder" (with fewer words and more numbers), and (5) by pushing harder, using their leverage on their customers and investees in their value chains and promote forward-looking, integrated and (assured) reporting thereon.

\section{The urgent calls for action:}

The call for action is for the financial sector as it has a duty and an opportunity to be a trusted steward, even an active driver in their value chains (i.e., with their customers and investees) of sustainable, shared value creation by research and creative, catalytic capital mobilization: more can be done, prudently and profitably.

The call for action on governments, regulators and supervisors is to create the enabling environment (through policies, risk-sharing instruments and capital requirements) for the financial sector to become the stewards for a better world for their stakeholders and society-at-large, and to invest with ambition, at scale, for such world: much more needs to be done and urgently!

\section{Herman Mulder}

Chair SDG Charter Foundation (NL), co-founder and Chair of True Price, former Chair of GRI and former (co-)Head Group Risk Management at ABN AMRO Bank. 